\title{
SPECIES RICHNESS AND ABUNDANCE OF LOW-TRUNK HERB EPIPHYTES IN RELATION TO HOST TREE SIZE AND BARK TYPE, EASTERN AMAZONIA ${ }^{1}$
}

\author{
José Leonardo Lima Magalhães² e Maria Aparecida Lopes ${ }^{3}$
}

\begin{abstract}
The composition and structure of the low-trunk epiphytic herb assembly as well as its vertical distribution were studied. DBH of host tree and bark type influence species richness and abundance in a nonflooded lowland tropical rainforest in Eastern Amazonia (1 $\left.{ }^{\circ} 57^{\prime} 36^{\prime \prime} \mathrm{S} 51^{\circ} 36^{\prime} 55^{\prime \prime} \mathrm{W}\right)$. A total of 37 epiphytic herb species were identified, among which $60 \%$ were Araceae. Species richness and abundance of epiphytic herbs showed tendency of positive correlation with host tree size and no relationships with bark type. Low positive correlation may be a by-product of the predominance of trees with smaller diameter in our sample rather than a reflection of neutral relationship. The absence of relationships with bark type may be partially explained by the large number of secondary, generalist, hemi-epiphytes and also may reflect the absence of suitable substrate in trees with smaller diameter.
\end{abstract}

Keywords: Secondary hemi-epiphyte; Lowland tropical rainforest; Composition.

\section{RIQUEZA DE ESPÉCIES E ABUNDÂNCIA DE EPÍFITAS HERBÁCEAS DE FUSTE BAIXO EM RELAÇÃO AO TAMANHO DO HOSPEDEIRO ARBÓREO E AO TIPO DE CASCA, AMAZÔNIA ORIENTAL}

\begin{abstract}
RESUMO - A composição e estrutura da comunidade epifítica herbácea de fuste baixo, assim como sua distribuição vertical, foram estudadas. O DAP de hospedeiros arbóreos e o tipo de casca influenciam a riqueza e abundância dessas espécies em um trecho de floresta de terra firme na Amazônia Oriental (157'36"S 5136'55"W). Foram identificadas, no total, 37 espécies herbáceas epifíticas, sendo 60\% delas Araceae. A riqueza de espécies e a abundância de herbáceas epifíticas mostraram tendência de correlação positiva com o tamanho de hospedeiros arbóreos e nenhuma relação com o tipo de casca. Correlação positiva baixa pode ser um subproduto da predominância de árvores de menor diâmetro na amostragem em vez de refletir relação neutra. A ausência de relações com o tipo de casca deve ser parcialmente explicada pelo grande número de hemiepífitas secundárias, generalistas, e também refletir a ausência de substratos adequados em árvores de menor diâmetro.
\end{abstract}

Palavras-chave: Hemiepífita secundária; Floresta de terra firme; Composição.

\section{INTRODUCTION}

Epiphytic plants are recurrent in all humid tropical environments comprising about one third of all plants and $10 \%$ of the species in tropical forests (KRESS, 1986; BENZING, 1990). In more humid areas and midelevation altitudes, like the submontane forests of the Andes and the Atlantic Forest in southern Brazil, epiphytes may constitute up to $50 \%$ of the total number of species (GENTRY; DODSON, 1987a; CARDELÚS et al., 2006; KERSTEN; SILVA, 2006). The abundance and vertical distribution of these species reflect environmental gradients in both local and regional scales (GENTRY; DODSON, 1987a; TER STEEGE; CORNELISSEN, 1989; NIEDER et al., 2000).

Almost $80 \%$ of the epiphytic species in tropics occur in the upper canopy, and fewer and different ones occur in the lower parts of their phorophytes (BENZING, 1990; WOLF; FLAMENCO-S, 2003). Along the vertical gradient

\footnotetext{
${ }^{1}$ Recebido em 06.09.2013 aceito para publicação em 15.04.2015.

${ }^{2}$ Universidade Federal Rural da Amazônia, Programa de Pós-Graduação em Botânica Tropical, Belém, Pará, Brasil. E-mail: <jleobio@gmail.com>.

${ }^{3}$ Universidade Federal do Pará, Instituto de Ciências Biológicas, Belém, Pará, Brasil. E-mail: <maria@ufpa.br>.
} 
there is lower light incidence and less substrate availability, although higher humidity in the lower strata (TER STEEGE; CORNELISSEN, 1989). Due to the differential microclimate of the understory, species that are more sensitive to desiccation as well as hemi-epiphytic individuals seeking appropriate photic levels are more abundant in this stratum (NIEDER et al., 2000).

The number of low-trunk epiphytic species and individuals may be correlated with the trunk diameter of their host trees (CALLAWAY et al., 2002; MORAN et al., 2003; ZOTZ; VOLLRATH, 2003; MEHLTRETER et al., 2005). Larger trees are available as hosts for a longer period of time and usually have more surface area than smaller trees (FLORES-PALACIOS; GARCÍAFRANCO, 2006; LAUBE; ZOTZ, 2006). On the other side, too old decaying trees with loosing bark offer a less favorable site to epiphytes (FLORES-PALACIOS; GARCÍA-FRANCO, 2006). Bark type also influences epiphytic richness and abundance (CALLAWAY, et al. 2002). Rough barks offer more microhabitats for seed germination and root attachment facilitating epiphyte establishment (BENZING, 1990; LAUBE; ZOTZ, 2006; TEWARI et al., 2009; CHOMBA et al., 2011).

The ecological knowledge about vascular epiphytes in Brazilian Amazon in currently still incipient, with a modest number of studies carried out in the biome (POS; SLEEGERS, 2010; MEDEIROS; JARDIM, 2011; IRUME et al., 2013; KOCH et al., 2013; QUARESMA; JARDIM, 2012, 2013, 2014; OBERMULLER et al., 2014). Epiphytic plants are important components of the tropical forest ecosystem and understanding their relationship with environment, including tree hosts, may help to predict their occurrence and to plan their conservation.

This study describes the composition and structure of the low-trunk epiphytic herb assembly in Caxiuanã National Forest, eastern Amazonia. We also investigate the following hypothesis based on previous cited literature and theory: (1) species richness and (2) number of individuals increase with DBH of host trees; and rough-barked trees have more (3) species and (4) individuals than fissured-and smooth- barked trees.

\section{MATERIALAND METHODS}

\subsection{Study site}

This study was carried out in a $25 \mathrm{~km}^{2}$ trail grid established at the center of the Caxiuanã National Forest
$-\mathrm{CNF}-\left(1^{\circ} 57^{\prime}-2^{\circ} 0\right.$ 'S and $\left.51^{\circ} 36^{\prime}-51^{\circ} 39^{\prime} \mathrm{W}\right)$, Eastern Amazonia (Figure 1). This trail grid belongs to a longterm Brazilian research program in biodiversity (PPBio/ Eastern Amazônia). This research program aims to execute standardized protocols along Eastern Amazon rainforest prospecting biodiversity and maintaining biological collections in order to integrate and disseminate information in biodiversity (ppbio.museu-goeldi.br).

The climate at Caxiuanã is $\mathrm{Am}_{\mathrm{i}}$, humid tropical, according to Köppen's classification, with more intense rainfall from December to June, an annual average rainfall of $1900 \mathrm{~mm}$ and an average annual temperature around $26^{\circ} \mathrm{C}$ (COSTA; MORAES, 2002; OLIVEIRA et al., 2008). The canopy at CNF is dense and closed; trees can be thirty to forty meters tall, some with large basal areas (LISBOA et al., 1997). The understory is sparse, with few lianas of genus such as Bauhinia, Tetracera, Doliocarpus, Desmoncus (AMARAL et al., 2009), terrestrial herbs such as Ischnosiphon, Calathea and Pariana (AUTHOR, unpublished results) and many tree species that reach 150-180 species per hectare and include many individuals with large DBH (AMARAL et al., 2009).

\subsection{Data collection and analysis}

Between March and September 2009, thirty transects of $2 \mathrm{~m} \times 100 \mathrm{~m}\left(6000 \mathrm{~m}^{2}\right)$ separated systematically by one kilometer were used to inventory the low-trunk epiphytic herb assembly (Figure 1). Within these transects all trees and treelets with $\mathrm{DBH} \geq 1 \mathrm{~cm}$ with at least one epiphytic individual were surveyed, as well as trunks of standing and fallen dead trees. In all cases only the bottom of the stem up to $8 \mathrm{~m}$ high were examined. For trees, this part was called low-trunk (TER STEEGE; CORNELISSEN, 1989). All epiphytes were counted, and morphotyped, and the height at which each one occurred was recorded. When the morphotype was not easily recognized in situ, the specimen was collected. Clonal plants were counted as single individuals when we were sure about it was a single genet, based on visual separation. Botanical samples from all morphospecies, with fertile material when possible, were collected and dried for subsequent identification.

These collected materials were identified in the laboratory with help of specialized literature (STEYERMARK etal., 1995; MAYO etal., 1997; RIBEIRO et al., 1999; SILVA; ROSÁRIO, 2008; ZUQUIM et al.,

Revista Árvore, Viçosa-MG, v.39, n.3, p.457-466, 2015

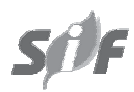



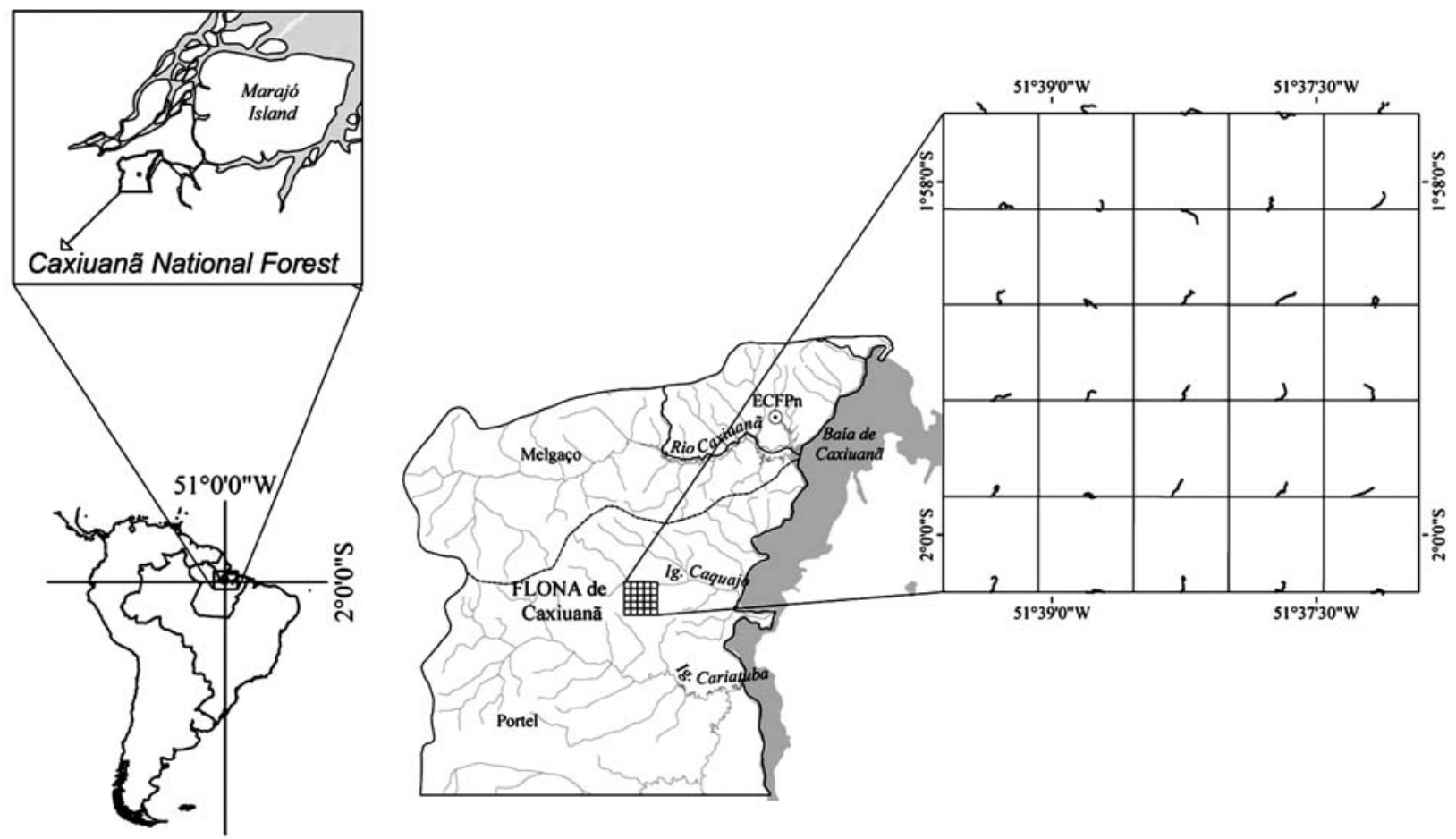

Figure 1 - Study area with location of PPBIO/Eastern Amazonia site, the trail grid at the center of the Caxiuanã National Forest.

Figura 1 - Área de estudo com a localização do sítio do PPBIO/Amazônia Oriental, a grade de trilhas no centro da FLONA de Caxiuanã.

2008) and by comparison with herbarium specimens. The fertile material was deposited in the Herbarium João Murça Pires MG. Identification of Monilophyta followed Smith et al. (2006) and of Magnoliophyta followed APG II (2003). Species and authors names were checked on the site Tropicos (2013) available at www.tropicos.org (last access 10/01/2013) and synonyms were verified in the World Checklist of Selected Plant Families (2013) available at http://apps.kew.org/ wcsp (last access 10/02/2013). All identified morphospecies were considered different species in the analysis.

Epiphytes were classified based on their relationship to the host trees (following BENZING, 1990) as holoepiphytes, hemi-epiphytes (primary and secondary), facultative epiphytes and accidental epiphytes. When the species identification was not possible, it was based on classification found in the literature about the genus.

All species encountered were included to compose the list of epiphytic herbs and to describe the assembly structure (frequency, relative abundance and vertical distribution), regardless of the type of phorophyte $(n=739)$. Only host trees whose DBH measures were available in previous study data set $(n=246)$ were used to test hypotheses 1) and 2); and only host trees identified to the species level $(n=79)$ were included to test hypotheses 3 ) and 4). Bark was classified as rough $(n=28)$, fissured $(\mathrm{n}=25)$ and smooth $(\mathrm{n}=26)$ based on descriptions available in the literature (RIBEIRO et al., 1999).

For each species, the frequency of occurrence $\left(\mathrm{F}=\left[\mathrm{n}_{\mathrm{i}} / \mathrm{n}_{\mathrm{t}}\right] \times 100\right.$, where $\mathrm{n}_{\mathrm{i}}=$ number of phorophytes supporting the species $\mathrm{i}, \mathrm{n}_{\mathrm{t}}=$ total number of hosts) and relative abundance $\left(\mathrm{RA}=\left[\mathrm{ne}_{\mathrm{i}} / \mathrm{ne}_{\mathrm{t}}\right] \times 100\right.$, where $\mathrm{ne}_{\mathrm{i}}=$ number of individuals of epiphytic species $i, \mathrm{ne}_{\mathrm{t}}=$ total number of epiphytic individuals) were calculated. The vertical distribution was evaluated for all epiphytic families and genera that had at least five individuals along the vertical gradient. The species cumulative curve and nonparametric bootstrap were used to assess representativeness of the sampling effort with $95 \%$ confidence with100 randomizations (MAGURRAN, 2004). 
Variables tested were not normal or homocedastic, so non-parametrical statistics were used in all cases. Hypotheses 1) and 2) were tested applying Spearman's correlation rank, and hypotheses 3 ) and 4) were tested applying Kruskal-Wallis, all considering $\mathrm{p} \leq 0.05$. Analyses were performed with R 2.15 (R DEVELOPMENT CORE TEAM, 2005), EstimateS 8.0 (COLWELL, 2006) and PAST (HAMMER et al., 2001).

\section{RESULTS}

In total 1,091 epiphytic herb individuals were found on 739 phorophytes, distributed in 10 families and 37 morphospecies comprising at least 30 species (Table 1). Only one form of the genera Micrograma and Catasetum was recorded, suggesting that only one species of each genus occurs in the area. About $70 \%$ of the sampled individuals were in juvenile stages and, of these, $40 \%$ could only be identified as morphospecies.

Twelve species were categorized as holo-epiphytes, 25 as secondary hemi-epiphytes and there were no reports of facultative, accidental or primary hemiepiphytes (Table 1). In Araceae, only one species was not a hemi-epiphyte, Anthurium gracile, which is a holoepiphyte. This species was associated with ants as were two other species, Aechmea bromeliifolia (Bromeliaceae) and Codonanthe calcarata (Gesneriaceae).

The botanical family with the greatest richness was Araceae with 23 species ( $62 \%$ of the total), followed by Pteridaceae with three species ( $8 \%$ ). The three most abundant families were Araceae, Pteridaceae and Lomariopsidaceae which together accounted for $99 \%$ of the individuals sampled. The remaining families contributed with one or two species and no more than 12 individuals.

The great majority of epiphytes occurred on the lower three meters of the trunk, particularly ferns and allies probably due to their great demand of humidity (Figure 2A). Cyclanthaceae and Polypodiaceae were the most evenly distributed families (Figure 2B), occurring frequently up to $5 \mathrm{~m}$ high.

The species rarefaction curve (Figure 3 ) showed no apparent asymptote, but it did tend toward stabilization. With the non-parametric bootstrap statistical test we estimated a richness equivalent to $41 \pm 8$ species, indicating that this study reached about $90 \%$ of the expected richness.

Revista Árvore, Viçosa-MG, v.39, n.3, p.457-466, 2015
Both species richness ( Spearman $=0.15, \mathrm{p}=0.01)$ and abundance $($ Spearman $=0.23, p=0.0002)$ showed $a$ tendency of positive correlation with DBH (Figure 4). Rough-barked trees did not have more species richness (Kruskal-Wallis $=0.27, \mathrm{p}=0.83$ ) and abundance (KruskalWallis $=0.1, p=0.93$ ) than fissured- and smooth-barked trees.

\section{DISCUSSION}

The epiphytic herb assembly at CNF showed a relatively low number of species (30-37) compared to studies carried out in Amazonia (NIEDER et al., 2000; BUSSMANN, 2001;LEIMBECK; BALSLEV, 2001; KREFT et al., 2004; KÜPER et al., 2004; BENAVIDES et al., 2005; ARÉVALO; BETANCUR, 2006; POS; SLEEGERS, 2010; IRUME et al., 2013) and the Guyanas (TER STEEGE; CORNELISSEN, 1989; FREIBERG, 1996). However, one should take into account the fact that only the understory was inventoried, and only herb species were considered. Species richness of epiphytes is often lower on trunks than on the higher parts of the same phorophyte because of the reduced amount of surface available for attachment (TER STEEGE; CORNELISSEN, 1989). Mehltreter et al. (2005) studied the low-trunk epiphyte assembly at a high altitude forest in Veracruz, Mexico and found around $20 \%$ more species (55 in total) than we found at CNF. According to Gentry and Dodson (1987b) the contribution of epiphytic species to the whole diversity of an area varies according to the different forest type and is usually smaller in lowland forests such as in the CNF. On the other hand, Araceae usually presents high species richness and abundance in lowland forest (IBISCH et al., 1996).

As was observed by Ter Steege and Cornelissen (1989) in Guyana, Nieder et al. (2000) in Venezuela and Irume et al. (2013) in central Amazonia, the most representative group in the assembly of epiphytes on the trunks at CNF were Araceae. The concentration of species in a few families reflects their specialization for the existing understory microhabitats (GENTRY; DODSON, 1987a; NIEDER et al., 2001). The low number or absence of typically reported orchids and bromeliads might be associated with the fact that epiphytic species in these families occupy preferentially the upper strata of the forest. These plants are highly adapted to support the wider range of humidity and temperature in these strata (TER STEEGE; CORNELISSEN, 1989; BENZING, 1990; CALLAWAY et al., 2002). During a survey of 
the epiphytes on 10 large trees in the same area of this study (CNF), POS and SLEEGERS (2010) found orchids and bromeliads only in the tree canopies, while aroids were found predominantly on the lower part of the trunks.

The predominance of hemi-epiphytic species was also reported for other studies in Amazonia (TER STEEGE; CORNELISSEN, 1989; NIEDER et al., 2000; BUSSMAN,
2001; LEIMBECK; BALSLEV, 2001; ARÉVALO; BETANCUR, 2006; IRUME et al., 2013). Moreover, most low-trunk epiphytic species and individuals found at CNF were concentrated on the lowest three meters of the trunks, what was evidenced with high number of secondary hemi-epiphytes. These species need to connect with the ground at some point in their life cycle (BENZING, 1990) which is why, when escalating

Table 1 - Species list of low-trunk epiphytic herb species and their relationship with host tree, classified according to relative abundance.

Tabela 1 - Lista de espécies de herbáceas epifíticas de fuste baixo e suas relações com hospedeiros arbóreos, classificadas segundo sua abundância relativa.

\begin{tabular}{|c|c|c|c|c|}
\hline $\begin{array}{l}\text { Species/ } \\
\text { Morphospecies }\end{array}$ & Family & $\begin{array}{c}\text { Relationship } \\
\text { with host tree }\end{array}$ & $\begin{array}{c}\text { Relative } \\
\text { abundance (\%) }\end{array}$ & $\begin{array}{c}\text { Frequency } \\
(\%)\end{array}$ \\
\hline Polytaenium guayanense (Hieron.) Alston & Pteridaceae & E & 21.1 & 17.6 \\
\hline Heteropsis flexuosa (Kunth) G. S. Bunting & Araceae & SHE & 15.4 & 19.0 \\
\hline Lomariopsis japurensis (Mart.) J. Sm. & Lomariopsidaceae & SHE & 11.8 & 13.3 \\
\hline Philodendron surinamense (Miq.) Engl. & Araceae & SHE & 8.1 & 8.0 \\
\hline Philodendron platypodum Gleason & Araceae & SHE & 7.8 & 9.4 \\
\hline Hecistopteris pumila (Spreng.) J. Sm. & Pteridaceae & E & 6.5 & 1.2 \\
\hline Heteropsis spruceana Schott & Araceae & SHE & 4.2 & 5.1 \\
\hline Philodendron sp. 2 & Araceae & SHE & 4.1 & 3.9 \\
\hline Monstera obliqua Miq. & Araceae & SHE & 3.6 & 3.5 \\
\hline Philodendron sp. 1 & Araceae & SHE & 3.3 & 4.0 \\
\hline Philodendron rudgeanum Schott & Araceae & SHE & 2.0 & 1.2 \\
\hline Philodendron linnaei Kunth. & Araceae & SHE & 1.3 & 1.6 \\
\hline Asplenium serratum L. & Aspleniaceae & $\mathrm{E}$ & 1.3 & 1.6 \\
\hline Monstera adansonii Schott & Araceae & SHE & 1.3 & 1.3 \\
\hline Campyloneurum repens (Aub1.) C. Pres1 & Polypodiaceae & $\mathrm{E}$ & 1.2 & 1.3 \\
\hline Philodendron squamiferum Poepp. & Araceae & SHE & 1.2 & 1.3 \\
\hline Philodendron melinonii Brongn. ex Regel & Araceae & SHE & 0.7 & 0.6 \\
\hline Philodendron pedatum (Hook.) Kunth & Araceae & SHE & 0.7 & 0.6 \\
\hline Evodianthus funifer (Poit.) Lindm. & Cyclanthaceae & SHE & 0.6 & 0.6 \\
\hline Codonanthe calcarata (Miq.) Hanst. & Gesneriaceae & $\mathrm{E}$ & 0.5 & 0.6 \\
\hline Philodendron fragantissimun (Hook.) G. Don & Araceae & SHE & 0.5 & 0.6 \\
\hline Anthurium sp. 2 & Araceae & SHE & 0.4 & 0.2 \\
\hline Philodendron ecordatum Schott. & Araceae & SHE & 0.4 & 0.5 \\
\hline Anthurium gracile (Rudge) Schott & Araceae & SHE & 0.3 & 0.4 \\
\hline Lomariopsis prieuriana Fée & Lomariopsidaceae & SHE & 0.3 & 0.4 \\
\hline Polytaenium cajenense (Desv.) Benedict & Pteridaceae & $\mathrm{E}$ & 0.3 & 0.4 \\
\hline Asplenium juglandifolium Lam. & Aspleniaceae & SHE & 0.2 & 0.2 \\
\hline Micrograma sp. & Polypodiaceae & $\mathrm{E}$ & 0.2 & 0.2 \\
\hline Philodendron sp. 3 & Araceae & SHE & 0.2 & 0.1 \\
\hline Trichomanes ankersii C. Parker ex Hook. and Grev. & Hymenophyllaceae & $\mathrm{E}$ & 0.2 & 0.2 \\
\hline Aechmea bromeliifolia (Rudge) Baker & Bromeliaceae & E & 0.1 & 0.1 \\
\hline Anthurium bonplandii G. S. Bunting & Araceae & SHE & 0.1 & 0.1 \\
\hline Anthurium sinuatum Benth. Ex Schott & Araceae & SHE & 0.1 & 0.1 \\
\hline Anthurium sp. 1 & Araceae & SHE & 0.1 & 0.1 \\
\hline Catasetum sp. & Orchidaceae & $\mathrm{E}$ & 0.1 & 0.1 \\
\hline Philodendron sp. 4 & Araceae & SHE & 0.1 & 0.1 \\
\hline Philodendron sp. 5 & Araceae & SHE & 0.1 & 0.1 \\
\hline
\end{tabular}

${ }^{1} \mathrm{E}=$ holo-epiphyte, SHE=secondary hemi-epiphyte. 

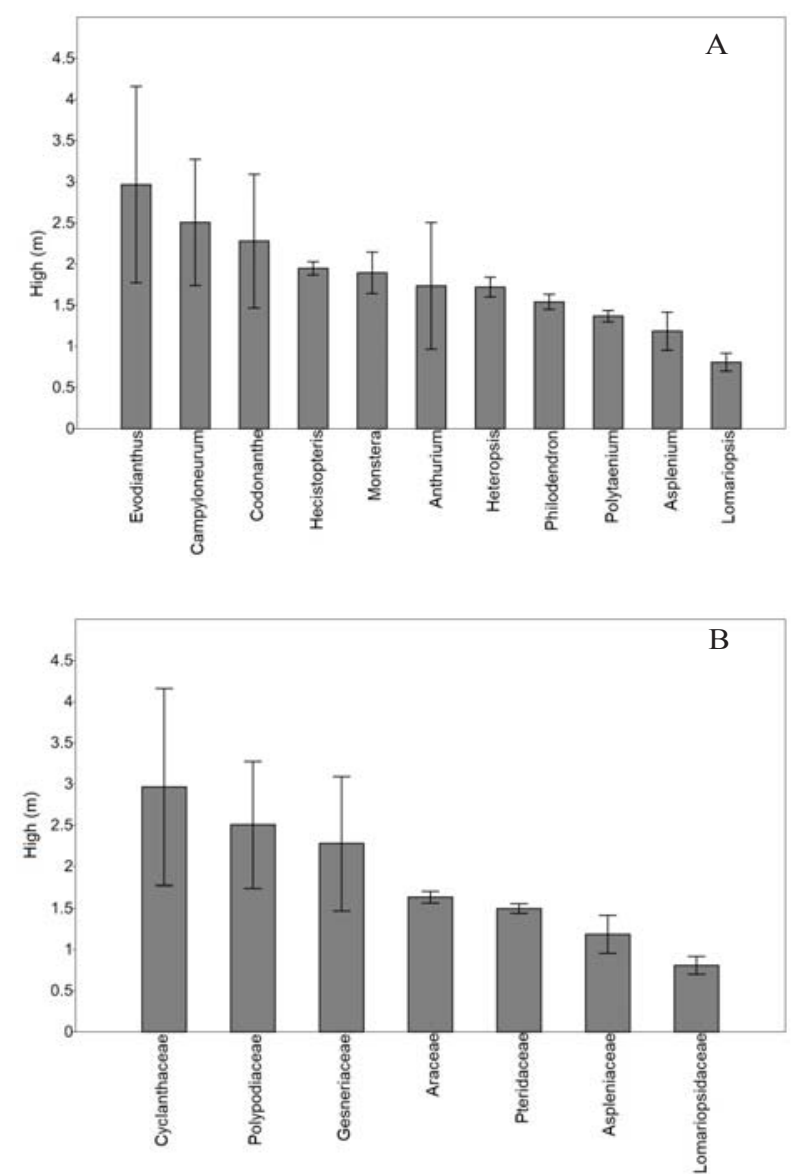

Figure 2 - Vertical distribution of low-trunk epiphytic herb genera (A) and family (B) in tree host at the Caxiuanã National Forest, Eastern Amazonia.

Figura 2 - Distribuição vertical dos gêneros (A) e famílias (B) de epífitas herbáceas de fuste baixo em hospedeiros arbóreos na FLONA de Caxiuanã, Amazônia Oriental.

a support close to where they germinate their juvenile stages were sampled in large numbers.

Epiphytic species richness and abundance showed positive correlation with $\mathrm{DBH}$, what was expected and confirmed by similar studies (CALLAWAY et al., 2002; MORAN et al., 2003; ZOTZ; VOLLRATH, 2003; MEHLTRETHER et al., 2005; FLORES-PALACIOS; GARCÍA-FRANCO, 2006). The low correlation found may have been at least partially affected by the predominance of smaller trees in our sample, weakening the detection of an expected stronger correlation.

Revista Árvore, Viçosa-MG, v.39, n.3, p.457-466, 2015

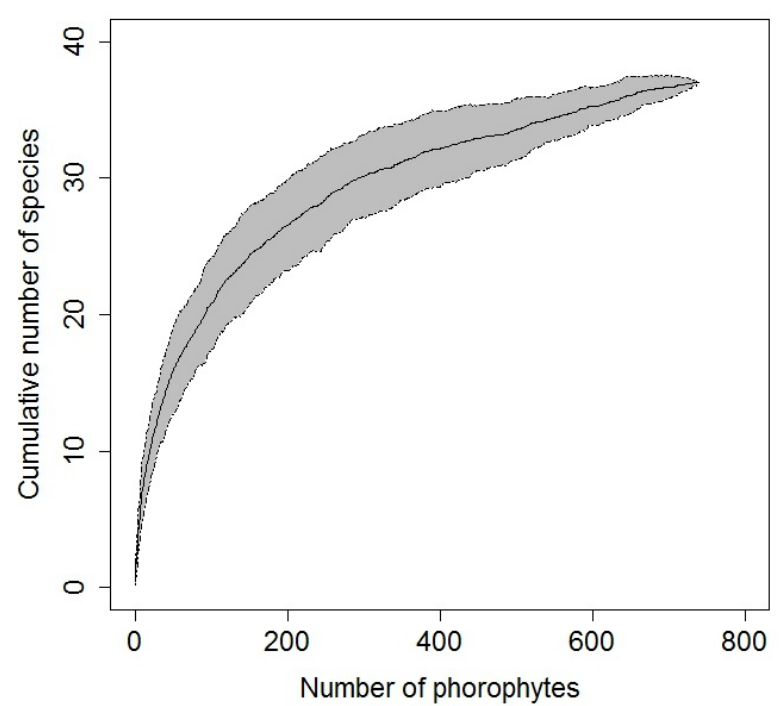

Figure 3 - Species accumulation curve (line) of epiphytic herb species sampled on 739 phorophytes with $95 \%$ confidence (light gray) with 100 randomizations, in the Caxiuanã National Forest, Eastern Amazonia.

Figura 3 - Curva cumulativa de espécies (linha) de epífitas herbáceas amostradas em 739 forófitos com 95\% de confiança (cinza claro) e 100 aleatorizações, na FLONA de Caxiuanã, Amazônia Oriental.

On the other hand, no relationship with bark type was found, contrary to what is generally found in other studies in lowland tropical rainforests (BENZING, 1990; LAUBE; ZOTZ, 2006; TEWARI et al., 2009; CHOMBA et al., 2011). Wyse and Burns (2011) found similar pattern in a temperate New Zealand rainforest but they covered all vertical gradients in four specific host trees species; instead of our assembly sample. This absence of correlation may be partially explained by the large number of secondary hemi-epiphytes which are substrate generalists (TER STEEGE; CORNELISSEN, 1989), but also probably may reflect the absence of suitable substrate in smaller trees.

\section{CONCLUSION}

Epiphytes are a key component of tropical forest in Amazonia but is not enough studied yet. Its relationships with host trees and bark type are important to enhance ecological knowledge about high diverse environments like Amazon forest and to increase biodiversity information. Furthermore, it is clear that, in others studies in Amazonia, hemi-epiphytes are driving 

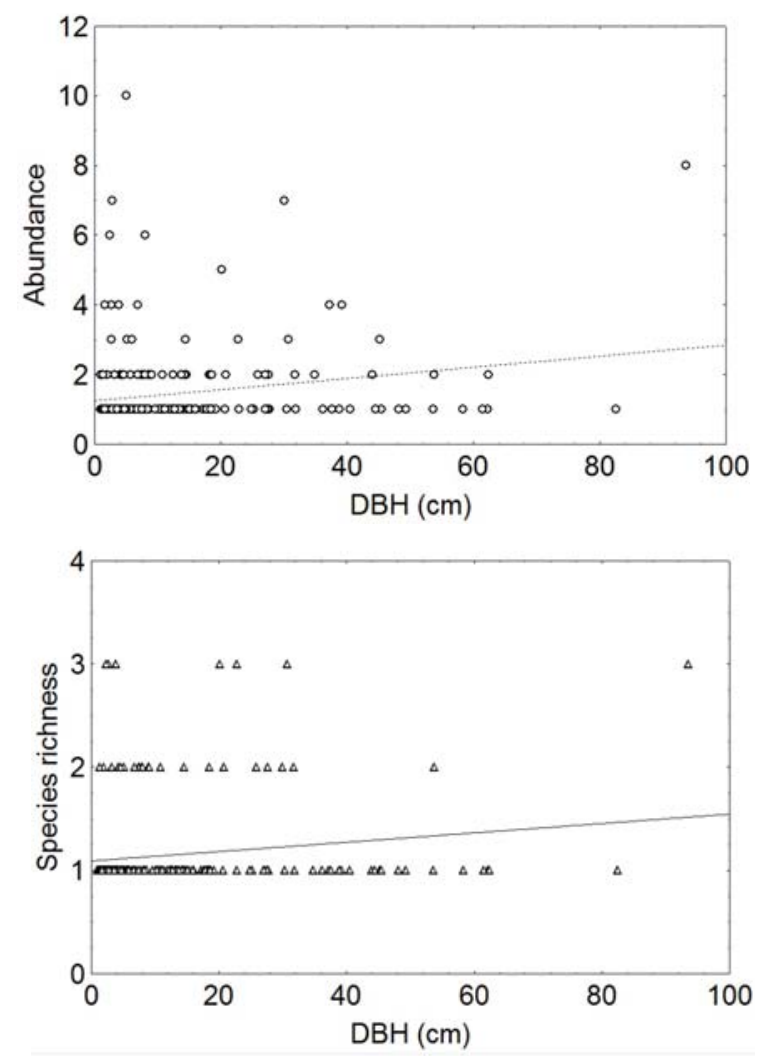

Figure 4-Correlation between species richness (Spearman $=0.15$, $\mathrm{p}=0.01$ - triangle) and abundance (Spearman $=0.23$, $\mathrm{p}=0.0002$ - dots) of epiphytic herb species versus DBH of host trees in the Caxiuanã National Forest, Eastern Amazonia.

Figura 4 - Correlação entre riqueza de espécies (Spearman $=0,15, p=0,01$ - triângulo) e abundância (Spearman $=0,23, p=0,0002$ - pontos) de epífitas herbáceas e DAP de hospedeiros arbóreos na FLONA de Caxiuanã, Amazônia Oriental.

for different pressures than holo-epiphytes. Future analysis should differentiate both growth habitats and also should be important determine the effect of life stage in low trunk epiphytic species on different host sizes.

\section{ACKNOWLEDGEMENTS}

We thank the Coordenação de Aperfeiçoamento de Pessoal de Nível Superior (CAPES) for granting the scholarship to the first author. The Universidade Federal Rural da Amazônia and Museu Paraense Emílio Goeldi for technical and logistical support. The Coordenação do Programa de Pesquisa em Biodiversidade
(PPBio - Eastern Amazônia) for providing access to their tree database, as well as financial and logistical support.

\section{REFERENCES}

THE ANGIOSPERM PHYLOGENY GROUP-APG II. An update of the Angiosperm Phylogeny Group classification for the orders and families of flowering plants: APG II. Botanical Journal of the Linnean Society, v.141, p.399-436. 2003.

AMARAL, D.D.; ALMEIDA, S.S.; COSTA, D.C.T. Contribuições ao manejo florestal de espécies de valor madeireiro e não madeireiro na Floresta Nacional de Caxiuanã. In: LISBOA, P.L.B. (Ed.) Caxiuanã, desafios para a conservação de uma Floresta Nacional na Amazônia. Belém: MPEG, 2009. p.199-228.

ARÉVALO, R.; BETANCUR, J. Vertical distribution of vascular epiphytes in four Forest types of the Serranía de Chiribiquete, Colombian Guyana. Selbyana, v.27, n.2, p.175-185, 2006.

BENAVIDES, A.M.D.; DUQUE, A.J.; DUIVENVOORDEN, J.F.; VASCO, G.A.; CALLEJAS, R. A first quantitative census of vascular epiphytes in rain forests of Colombian Amazonia. Biodiversity and

Conservation, v. 14, p.739-758, 2005.

BENAVIDES, A.M.; VASCO, A.; DUQUE, A.J.; DUIVENVOORDEN, J.F. Association of vascular epiphytes with landscape units and phorophytes in humid lowland forests of Colombian Amazonia. Journal of Tropical Ecology, v.27, p.223$237,2011$.

BENZING, D.H. Vascular epiphytes. Cambridge: Cambridge University Press, 1990.

BUSSMANN, R.W. Epiphyte diversity in a tropical Andean Forest - Reserva Biológica San Francisco, Zamora-Chinchipe, Ecuador. Ecotropica, v.7, p.43-59, 2001.

CALLAWAY, R.M.; REINHART, K.O.; MOORE, G.W.; MOORE, D.J.; PENNINGS, S.C. Epiphyte host preferences and host traits: mechanisms for species-specific interactions. Oecologia, v.132, p.221-230, 2002.

Revista Árvore, Viçosa-MG, v.39, n.3, p.457-466, 2015 
CARDELÚS, C.L.; COLWELL, R.K.; WATKINS J.E. Vascular epiphyte distribution patterns: explaining the mid-elevation richness peak. Journal of Ecology, v.94, p.144-156, 2006.

CHOMBA, C.; SENZOTA, R.; CHABWELA, H.; NYIRENDA, V. The influence of host tree morphology and stem size on epiphyte biomass distribution in Lusenga Plains National Park, Zambia. Journal of Ecology and Natural Environment, v.3, n.12, p.370-380, 2011.

COLWELL, R.K. EstimateS: Estatistical estimation of species richness and shared species from samples, Versão 8. 2006.

COSTA, J.P.R.; MORAES, J.C. Médias mensais de variáveis metereológicas (1996-1999). In: LISBOA, P.L.B. (Ed.) Caxiuanã. Belém: MPEG, 2002. p.225-232.

FLORES-PALACIOS, A.; GARCÍA-FRANCO, J. Habitat isolation changes the beta diversity of the vascular epiphyte community in lower montane forest, Veracruz, Mexico.

Biodiversity and Conservation, v.17, p.191-207, 2006.

FREIBERG, M. Spatial distribution of vascular epiphytes on three emergent canopy trees in French Guiana. Biotropica, v.28, n.3, p.345355, 1996.

GENTRY, A.H.; DODSON, C.H. Contribution of non-trees to species richness of tropical rain forest. Biotropica, v.19, n.2, p.149-156, $1987 \mathrm{a}$

GENTRY, A.H., DODSON, C.H. Diversity and biogeography of neotropical vascular epiphytes. Annals of the Missouri Botanical Garden, v.74, p.205-233, 1987 b.

HAMMER, O.; HARPER, D.A.T.; RYAN, P.D. PAST: Paleontological statistics software package for education and data analysis. Paleontologia Electronica, v.4, n.1, p. 1 9, 2001 .

IBISCH, P.L.; BOEGNER, A.; NIEDER, J.; BARTHLOTT, W. How diverse are neotropical epiphytes? An analysis on the "Catalogue of

Revista Árvore, Viçosa-MG, v.39, n.3, p.457-466, 2015 the flowering plants and gymnosperms of Peru". Ecotropica, v.2, n.2, p.13-28, 1996.

IRUME, M.V.; MORAIS, M.L.C.S.; ZARTMAN, C.E.; AMARAL, I.L. Floristic composition and community structure of epiphytic angiosperms in a terra firme forest in central Amazonia. Acta Botanica Brasilica, v.27, n.2, p.278-393, 2013.

KERSTEN, R.A., SILVA, S.M. The floristic compositions of vascular epiphytes of a seasonally inundated Forest on the coastal plain of Ilha do Mel Island, Brazil. Revísta de Biología Tropical, v.54, n.3, p.935-942, 2006

KOCH, A.K.; SANTOS, J.U.M.; ILKIU-BORGES, A.L. Bromeliaceae epífitas de uma Área de Conservação da Amazônia brasileira.

Rodriguésia, v.64, n.2, p.419-425, 2013.

KREFT, H.; KÖSTER, N.; KÜPER, W.; NIEDER, J.; BARTHLOTT, W. Diversity and biogeography of vascular epiphytes in Western Amazonia, Yasuní, Ecuador. Journal of

Biogeography, v.31, p.1463-1476, 2004.

KRESS, J.W. The systematic distribution of vascular epiphytes: an update. Selbyana, v.9, p.2-22, 1986.

KÜPER, W.; KREFT, H.; NIEDER, J.; KÖRTER, N.; BARTHLOTT, W. Large-scale diversity patterns of vascular epiphytes in Neotropical montane rain forests. Journal of

Biogeography, v.31, p.1477-1487, 2004.

LEIMBECK, R.M.; BALSLEV, H. Species richness and abundance of epiphytic Araceae on adjacent floodplain and upland forest in Amazonian Ecuador. Biodiversity and Conservation, v.10, p.1579-1593, 2001.

LAUBE, S.; ZOTZ, G. Neither host-specific nor random: vascular epiphytes on three tree species in a Panamanian lowland forest. Annals of Botany, v.97, p.1103-1114, 2006.

LISBOA, P.L., ALMEIDA, S.S., SILVA, A.S.L. Florística e estrutura dos ambientes. In: LISBOA, P.L.B. (Ed.) Caxiuanã. Belém: MPEG, 1997. p.163-193. 
MAGURRAN, A. Measuring biological diversity. London: Blackwell Science, 2004.

MAYO, S.J.; BOGNER, J.; BOYCE, P.C. The genera of Araceae. Kew: Royal Botanic Gardens, 1997.

MEDEIROS, T.D.S.; JARDIM, M.A.G. Distribuição vertical de orquídeas epífitas na Área de Proteção Ambiental (APA) Ilha do Combu, Belém, Pará, Brasil. Revista Brasileira de Biociências, v.9, n.1, p.33-38, 2011.

MEHLTRETER, K.; FLORES-PALACIOS, A.; GARCÍA-FRANCO, J.G. Host preferences of lowtrunk vascular epiphytes in a cloud forest of Veracruz, Mexico. Journal of Tropical Ecology, v.21, p.651-660, 2005.

MORAN, R.C.; KLIMAS, S.; CARLSEN, M. Low-trunk epiphytic ferns on tree ferns versus angiosperms in Costa Rica. Biotropica, v.35, n.1, p.48-56, 2003.

NIEDER, J.; ENGWALD, S.; KLAWUN, M.; BARTHLOTT, W. Spatial distribution of vascular epiphytes (including hemiepiphytes) in a lowland Amazonian rain forest (Surumoni Crane Plot) of Southern Venezuela. Biotropica, v.32, n.3, p.385-396, 2000.

NIEDER, J.; PROSPERÍ, J.; MICHALOUD, G. Epiphytes and their contribution to canopy diversity. Plant Ecology, v. 153, n.2, p.51-63, 2001.

OBERMULLER, F.A.; FREITAS, L.; DALY, D.C.; SILVEIRA, M. Patterns of diversity and gaps in vascular (hemi-) epiphyte flora of Southwestern Amazonia. Phytotaxa, v.166, n.4, p.259-272. 2014.

OLIVEIRA, L.L.; COSTA, R.F.; SOUSA, F.A.S.; COSTA, A.C.L.; BRAGA, A.P. Precipitação efetiva e interceptação em Caxiuanã, na Amazônia Oriental. Acta Amazonica, v.48, n.4, p.723-732, 2008.

POS, E.T.; SLEEGERS, A.D.M. Vertical distribution and ecology of vascular epiphytes in a lownland tropical rainforest of Brazil.

Boletim do Museu Paraense Emílio Goeldi, Série Ciências Naturais, v.5, n.3, p.335-344, 2010.

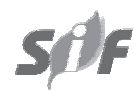

QUARESMA, A.C.; JARDIM, M.A.G.

Diversidade de bromeliáceas epífitas na Área de Proteção Ambiental Ilha do Combu, Belém, Pará, Brasil. Acta Botanica Brasilica, v.26, n.2, p.290294, 2012.

QUARESMA, A.C.; JARDIM, M.A.G.

Fitossociologia e Distribuição Espacial de Bromélias epifíticas em uma Floresta de Várzea Estuarina Amazônica. Revista Brasileira de Biociências, v.11, n.1, p.1-6, 2013.

QUARESMA, A.C.; JARDIM M.A.G. Floristic composition and spatial distribution of vascular epiphytes in the restingas of Maracanã, Brazil. Acta Botanica Brasilica, v.28, n.1, p.68-75, 2014.

R DEVELOPMENT CORE TEAM. R: A Language and Environment for Statistical Computing. Version 2.10. Vienna, Austria: 2005.

RIBEIRO, J.E.L.S.; HOPKINS, M.J.G.; VICENTINI, A.; SOTHERS, C.A.; COSTA, M.A.S.; BRITO, J.M.; SOUZA, M.A.D.; MARTINS, L.H.P.; LOHMANN, L.G.; ASSUNÇÃO, P.A.C.L.; PEREIRA, E.C.; SILVA, C.F.; MESQUITA, M.R.; PROCÓPIO, L.C. Flora da Reserva Ducke: guia de identificação das plantas vasculares de uma floresta de terra firme na Amazônia Central. Manaus: INPA/DFID, 1999.

SILVA, M.R.P.; ROSÁRIO, S.M. Licófitas e monilófitas (Pteridophyta) da Floresta Nacional de Caxiuanã, estado do Pará, Brasil: chave para as famílias e as espécies de Aspleniaceae e Blechnaceae. Boletim do Museu Paraense Emílio Goeldi, Série Ciências Naturais, v.3, n.2, p.151-163, 2008.

SMITH, A.R.; PRYER, K.M.; SCHUETTPELZ, E.; KORALL, P.; SCHNEIDER, H.; WOLF, P.G. A classification for extant ferns. Taxon, v.55, n.3, p.705-731, 2006.

STEYERMARK, J.S.; BERRY, P.E.; HOLST, B.K Flora of the Venezuelan Guayana. Portland: Timber Press, 1995.

TER STEEGE, H.; CORNELISSEN, J.H.C. Distribution and ecology of vascular epiphytes in lowland rain forest of Guyana. Biotropica, v.21, n.4, p.331-339, 1989.

Revista Árvore, Viçosa-MG, v.39, n.3, p.457-466, 2015 
TEWARI, L.M.; TEWARI, G.; NAILWAL, T.; PANGTEY, Y.P.S. Bark factors affecting the distribution of epiphytic ferns communities. Nature and Science, v.7, n.5, p.76-81, 2009.

TROPICOS, Org. Tropicos.org. Missouri Botanical Garden. 2013. [Accessed in 10 Jan. 2013] <http://www.tropicos.org >

WOLF, J.H.D.; FLAMENCO-S, A. Patterns in species richness and distribution of vascular epiphytes in Chiapas, Mexico. Journal of Biogeography, v.30, p.1689-1707, 2003.

WORLD CHECKLIST OF SELECTED PLANT FAMILIES. Facilitated by the Royal Botanic Gardens, Kew. 2013. [Accessed in 10 de Feb.
2013]. Published on the Internet; <http:// apps.kew.org/wcsp/>

WYSE, S.V.; BURNS, B.R. Do host bark traits influence trunk epiphyte communities? New Zealand Journal of Ecology, v. 35, n.3, p.296-301, 2011.

ZOTZ, G.; VOLLRATH, B. The epiphyte vegetation of the palm Socratea exorrhiza - correlations with tree size, tree age and bryophyte cover. Journal of Tropical Ecology, v.19, p.81-90, 2003.

ZUQUIM, G.; COSTA, F.R.C.; PRADO, J.;

TUOMISTO, H. Guia de samambaias e licófitas da REBIO Uatumã. Manaus: Amazônia Central/INPA, 2008. 